\title{
$\checkmark$ Research Square \\ Liver involvement by plasma cell myeloma mimicking clear cell carcinoma, a potential pitfall.
}

Fotini-Rosi Vagena ( $\nabla$ fotini.vagena@medunigraz.at)

Medizinische Universitat Graz https://orcid.org/0000-0001-5062-2156

Heinz Sill

Medizinische Universitat Graz

Christine Beham-Schmid

Medizinische Universitat Graz

\section{Case Report}

Keywords: Plasma cell myeloma, clear cell carcinoma

Posted Date: June 4th, 2020

DOI: https://doi.org/10.21203/rs.3.rs-32070/v1

License: (c) (1) This work is licensed under a Creative Commons Attribution 4.0 International License.

Read Full License 


\section{Abstract}

Background: Unusual morphological variants of plasma cell myeloma are a diagnostic challenge.

Case presentation: A 60 year old woman with low-back pain was diagnosed with a plasma cell myeloma in the bone marrow. Concurrently a tumour was found in the liver. The histological specimen of the liver resembled a clear cell carcinoma, but the immunophenotype revealed plasma cell myeloma.

Conclusion: In tumours with an extraordinary morphology and not conclusive immunohistochemical results the use of plasma cell antibodies may lead to the correct diagnosis.

\section{Background}

Plasma cell myeloma is a rather common neoplasm accounting $10-15 \%$ of the haematopoietic neoplasms and $20 \%$ of deaths from haematological neoplasms. In the WHO classification plasma cell myeloma ${ }^{1}$ is defined as a bone marrow-based, multifocal neoplastic proliferation of plasma cells, usually associated with an $\mathrm{M}$ protein in serum and /or urine and evidence of organ damage related to the plasma cell neoplasm. An extramedullary spread can occur. The most common morphological variants of plasma cell myeloma show a plasmacytic, plasmablastic or pleomorphic appearance. However, there are reports of unusual morphological variants, which do not reveal a plasmacytic morphology ${ }^{2-7}$.

\section{Case Presentation}

A 60 year old female patient with low-back pain lasting for about two months, had an MRT for diagnostic clarification. The MRT results showed osteodestructive lesions of the lumbar spine, the ribs and the iliac bone. CT-Scan showed a tumour-mass of $3.7 \mathrm{~cm}$ in diameter in the left ventral thorax-wall, a $3 \mathrm{~cm}$ in diameter osteodestructive lesion in L4 vertebral body and a tumour of $4 \mathrm{~cm}$ in diameter in the liver. A mammography was inconspicuous. The clinical picture was suspicious of a carcinoma of unknown primary. Further examination revealed elevated serum-levels of the immunoglobulin heavy chain $\lg A$ and the immunoglobulin light chain kappa. A bone marrow trephine biopsy was performed revealing infiltration by a plasma cell myeloma with typical morphology (Fig. 1A) and expression of the immunoglobulin heavy chain IgA, the immunoglobulin light chain kappa and co-expression of CD56. The extent of bone marrow infiltration was $25 \%$ compared to the haematopoiesis. Because of the tumorous lesions found in CT-scan a liver biopsy was performed to exclude a secondary neoplasm. The morphology of the liver tumour resembled a clear cell carcinoma. However various immunohistochemical stains for carcinoma were negative. With the knowledge of the patient's plasma cell myeloma, relevant plasma cell marker inclusive light and heavy chain antibodies were performed, leading to the correct diagnosis of a plasma cell myeloma. Despite extensive treatments, the disease progressed. A bone marrow biopsy taken 11 months after primary diagnosis showed neoplastic plasma cell infiltration, quantified by $98 \%$ compared to the haematopoiesis. The patient ultimately died of bone marrow failure. 


\section{Results}

The histological examination of the liver tumour showed tumour cells with round and partially cleaved nuclei with small nucleoli and a clear broad cytoplasm (Fig. 1B and C). Some tumour cells were polynucleated, some showed bizarre nuclei. The morphology resembled a clear cell carcinoma. Immunohistochemistry using antibodies against epithelial tumour cells and malignant melanoma were negative. Since the diagnosis of plasma cell myeloma was known, immunohistochemistry (Fig. 1D) with plasma cell markers was performed confirming a plasma cell myeloma in the liver.

\section{Discussion}

The diagnosis of an extramedullary plasmacytoma or an extramedullary involvement of a plasma cell myeloma usually is not challenging. The patient described here, had a clinical picture which was initially interpreted as a carcinoma of unknown primary („CUP"). The elevated serum levels of the Immunoglobulin heavy chain IgA and the Immunoglobulin light chain kappa led the clinicians to the diagnosis of a plasma cell myeloma. This neoplasm was confirmed by bone marrow biopsy. In the bone marrow the neoplastic plasma cells showed the typical morphology in contrast to the liver tumour.

In cases with unusual histological morphology the way to the correct diagnosis can be challenging. In this case the differential diagnosis of a second neoplasm such as undifferentiated malignant tumour had to be considered. The positivity for CD56 could be misinterpreted as neuroendocrine carcinoma. The differential diagnosis in specimens with CD56 positivity should include malignant lymphoma, poorly differentiated adenocarcinoma, clear cell carcinoma, high grade sarcoma and malignant melanoma ${ }^{8}$.

\section{Conclusion}

Although morphological variants of plasma cell myeloma are rare, a pathologist should be aware of their existence. In tumours with an extraordinary morphology and a not conclusive immunprofile the use of plasma cell antibodies may lead to the correct diagnosis.

\section{Abbreviations}

WHO, World Health Organisation,

CUP, carcinoma of unknown primary

\section{Declarations}

The study was performed according to the institutional guidelines and approved by the Ethics comity of the Medical University of Graz (Vote 32-150ex19/20).

Consent for publication: 
Written informed consent for publication not available and not necessary because of the death of the patient.

Availability of data and materials:

Institute of Pathology Medical University Graz

Authors contributions:

CBS and FRV participated in the design of the study and histopathological evaluation, and drafted the manuscript. HS revised the manuscript. All authors have given approval for the final version to be published.

Competing interest:

The authors declare that they have no competing interests.

Funding:

No funding has been gained by the authors for this research

\section{References}

1. Swerdlow SH, Campo E, Lee Harris N, Jaffe ES, Stefano SA. Pileri, et al. WHO Classification of tumours of Haematopoietic and Lymphoid Tissues. 4th Edition. Lyon: IARC; 2017.

2. Haidar JH, Bazarbachi A, Nasr MR, El-Sabban ME, Daher R. Signet ring-like light chain myeloma with systemic spread. Eur J Haematol. 2003;70:249-50.

3. Yeh YA, Pappas AA, Flick JT, Butch AW. A case of aggressive multiple myeloma with cleaved, multilobated, and monocytoid nuclei, and no serum monoclonal gammopathy. Ann Clin Lab Sci. 2000;30:283-8.

4. Banerjee SS, Verma S, Shanks JH. Morphological Variants of Plasma Cell Tumours. Histopathology. 2004;44:2-8.

5. Galani Z, Viniou N, Kyrtsonis MC, Sachanas S, Antoniou T, Dimopoulou MN, et al. Hepatic and Renal Plasma Cell Lesions in a Patient With Multiple Myeloma in Hematological Remission. Anticancer Res. 2007;27:571-4.

6. Lu T, Pu H, Zhao G. Primary pancreatic plasmacytoma: a rare case report. BMC Gastroenterol. 2017; 17:167.

7. Gupta R, Hussain N, Rahman K, Nityanand S. Plasma Cell Myeloma With Unusual Morphology-A Series of 6 Cases. Eur J Haematol. 2014;93:165-70.

8. Chen T, Ma CK, Nelson JW, Padmanabhan A, Brittin GM. Clear Cell Myeloma. Am J Surg Pathol. 1985;9:149-54. 


\section{Figures}

\section{Figure 1}

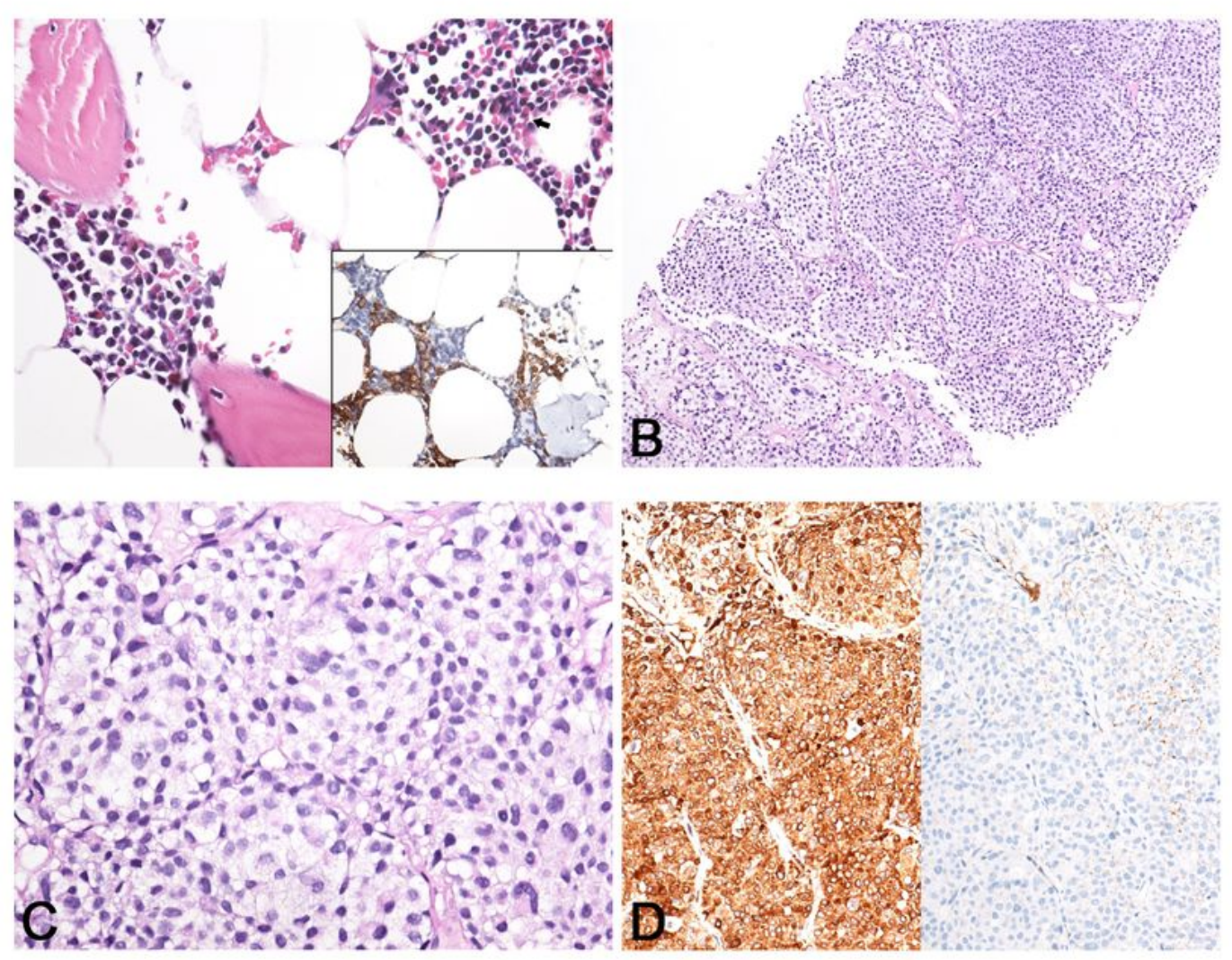

\section{Figure 1}

(A): Bone marrow biopsy, haematoxylin eosin staining, (the arrow points to the plasmacytically differentiated infiltrate) (40x) with inset picture of CD38 immunohistochemistry (40x). (B): Liver biopsy, 
haematoxylin eosin staining (10x). (C): Liver biopsy, haematoxylin eosin staining (20x). (D): Liver biopsy, immunohistochemistry (20x) Kappa (left) and lambda (right).

\section{Supplementary Files}

This is a list of supplementary files associated with this preprint. Click to download.

- CAREchecklist.docx 